\title{
Implementasi Pendidikan Karakter Melalui Model Pembelajaran Discovery Learning Di Mim Pasir Lor Karanglewas Banyumas
}

Ana Andriani $i^{*}$, Wakhudin ${ }^{2}$

1,2Universitas Muhammadiyah Purwokerto

*Corresponding author

E-mail: ana.andriani@gmail.com (Ana Andriani)*

Article History:

Received: $30-8-2020$

Revised: 8-9-2020

Accepted: 9-9-2020

Keywords:

\begin{abstract}
Artikel ini membicarakan tentang penerapan model pembelajaran discovery learning dalam proses pembelajaran sebagai implementasi dari pendidikan karakter pada siswa Madrasah Ibtidaiyah Muhammadiyah Pasir Lor Kec Karanglewas Kabupaten Banyumas. Realitas empirik memperlihatkan bahwa kondisi saat ini sangat memprihatinkan, banyak kasus di lingkungan masyarakat mengindikasikan menurunnya kualitas karakter peserta didik di sekolah saat ini. Pelanggaran norma bukan sekedar kesopanan kesusilaan, namun dapat meningkat pada pelanggaran hukum dan Agama. Banyak faktor yang menjadi penyebab terjadinya pelanggaran-pelanggaran itu, diantaranya adalah perkembangan teknologi informasi yang semakin canggih, perubahan gaya hidup yang sangat dinamis, kesibukan orang tua yang semakin tinggi yang menyebabkan perhatian terhadap anak-pun berkurang, menjadi faktor-faktornya. Pendidikan Karakter menjadi pendidikan yang sangat penting saat ini guna menumbuhkan karakter baik yang sebagai bagian dari softskill yang sangat berguna dalam kehidupan sehari-hari. Pendidikan karakter dapat disisipkan dalam pembelajaran apapun namun dengan model pembelajaran yang menyenangkan. Satu pernyataan bahwa tidak ada satu obat mujarab-pun di dalam dunia pendidikan, dapat dimaknai bahwa ada banyak ragam yang dapat digunakan dalam proses pembelajaran untuk tercapainya tujuan pendidikan nasional. Implementasi pendidikan karakter di sekolah dapat dilakukan dengan model pembelajaran yang disesuaikan dengan konten pengetahuannya. Model discovery learning diharapkan mampu menjadi model pembelajaran yang dapat meningkatkan karakter peserta didik.
\end{abstract}

Discovery Learning, Pendidikan Karakter, Madrasah Ibtidaiyah 


\section{Pendahuluan}

Kualitas pendidikan saat ini meliputi berbagai sektor dan jenjang pendidikan, termasuk jenjang pendidikan dasar. Pengembangan proses pembelajaran dalam jenjang pendidikan dasar yang terjadi adalah memposisikan siswa sebagai pendengar ceramah guru. Akibatnya proses belajar-mengajar cenderung membosankan dan menjadikan siswa malas belajar.

Kenyataan dalam pendidikan sekarang ini terdapat banyak masalah yang dihadapi pada saat proses pembelajaran. Salah satu masalah dari berbagai masalah yang terdapat dalam proses pembelajaran adalah kurangnya perhatian siswa pada saat proses pembelajaran berlangsung, khususnya pada saat pembelajaran terutama ilmu sosial. Masih banyak siswa yang asyik bermain dengan temannya daripada mendengarkan penjelasan guru. Di samping itu, model pembelajaran yang diterapkan guru kurang menarik dan membuat siswa bosan saat mengikuti pembelajaran, sehingga pemahaman siswa terhadap materi yang disampaikan oleh guru kurang.

Pada hakikatnya proses belajar-mengajar merupakan kegiatan yang dapat membantu siswa mencari tujuan pendidikan yang telah ditetapkan. Menurut Dimyati (2006: 286), hakikat pembelajaran diantaranya adalah (1) Kegiatan yang dimaksudkan untuk membelajarkan pembelajar; (2) Program pembelajaran yang dirancang dan diimplementasikan sebagai suatu sistem; (3) Kegiatan yang dimaksudkan untuk memberikan pengalaman belajar kepada pebelajar; (4) Kegiatan yang mengarahkan pebelajar ke arah pencapaian tujuan pembelajaran; dan (5) Kegiatan yang melibatkan komponen-komponen tujuan, isi pelajaran, sistem penyajian, dan sistem evaluasi dalam realisasinya.

Proses belajar mengajar dapat berjalan efektif apabila seluruh komponen yang berpengaruh dalam proses tersebut saling mendukung. Komponen tersebut antara lain siswa, guru, kurikulum, metode, sarana dan prasarana serta lingkungan sekolah. Menurut Djamarah (2002: 48), komponen dalam kegiatan belajar-mengajar meliputi tujuan, bahan pelajaran, kegiatan belajar mengajar, metode, alat dan sumber belajar, serta evaluasi.

Anak didik merupakan syarat mutlak bagi berlangsungnya kegiatan belajar mengajar. Selain itu, guru juga termasuk sebagai salah satu komponen dalam proses belajar mengajar karena guru memegang peran yang sangat penting. Guru bukan hanya sekedar penyampai materi saja, tetapi guru dapat dikatakan sebagai sentral pembelajaran yang mengarahkan bagaimana proses belajar mengajar itu dilaksanakan. Karena itu guru harus dapat membuat suatu pengajaran menjadi lebih efektif juga menarik sehingga bahan pelajaran yang disampaikan akan membuat siswa merasa senang dan merasa perlu untuk mempelajari bahan pelajaran tersebut. Hamalik (2008: 123) menjelaskan apa yang dikemukakan oleh Adam \& Dickey bahwa peran guru sesungguhnya sangat luas meliputi guru sebagai 
pengajar, pembimbing, guru juga sebagai penghubung dan modemisator serta pembangun.

Peran guru dalam menentukan keberhasilan tujuan pembelajaran pada kegiatan belajar mengajar amat besar bagi peserta didik, karena guru secara langsung dapat mempengaruhi, membina dan meningkatkan kecerdasan serta keterampilan siswa. Untuk mengatasi permasalahan di atas dan guna mencapai tujuan pendidikan secara maksimal, diharapkan guru memiliki cara maupun model mengajar yang baik dan tepat sesuai dengan konsep-konsep mata pelajaran yang akan disampaikan.

Kegiatan pembelajaran di sekolah merupakan kegiatan utama dalam proses pendidikan, kegiatan ini bertujuan membawa anak didik menuju keadaan yang lebih baik. Berhasil tidaknya proses pembelajaran dapat diketahui dari hasil belajar yang dicapai oleh siswa. Hasil belajar tersebut biasanya dikaitkan dengan tinggi rendahnya nilai yang diperoleh siswa tersebut.

Prestasi belajar merupakan tolak ukur untuk mengetahui keberhasilan siswa dari proses belajar mengajar. Siswa yang mendapatkan prestasi yang tinggi maka dapat dikatakan siswa tersebut berhasil dalam belajar. Menurut Tu'u (2004:75), prestasi belajar siswa adalah hasil belajar yang dicapai siswa ketika mengikuti dan mengerjakan tugas dan kegiatan pembelajaran di sekolah.

Pembelajaran pada umumnya masih berpusat pada guru, siswa tidak diarahkan untuk berfikir kreatif dan menguasai konsep berdasarkan penemuan-penemuan di lapangan. Dengan metode tersebut siswa kurang termotivasi untuk belajar bahkan umumnya siswa tidak memperhatikan penjelasan guru sehingga kemampuan siswa dalam memahami materi yang disampaikan menjadi kurang. Pembelajaran dengan model Discovery Learning diharapkan seorang guru akan mampu mengidentifikasi dan menetapkan permasalahan yang terjadi saat berjalannya proses pembelajaran, serta mampu menganalisis dan merumuskan masalah yang selanjutnya akan dilakukan sebuah tindakan perbaikan terhadap permasalahan yang ada pada saat pembelajaran. Karena model ini mempunyai potensi yang besar untuk meningkatkan suasana pembelajaran yang positif apabila diterapkan dengan baik dan benar.

Discovery Learning merupakan pembelajaran yang melibatkan siswa dalam proses kegiatan mental melalui tukar pendapat, berdiskusi, membaca sendiri dan mencoba sendiri, agar anak dapat belajar secara mandiri. Menurut Suryosubroto (2009:178), metode penemuan (discovery) merupakan komponen dari praktik pendidikan yang meliputi metode mengajar yang memajukan cara belajar aktif, berorientasi pada proses, mengarahkan sendiri, mencari sendiri, dan reflektif. Dalam metode pembelajaran discovery learning siswa lebih aktif dalam memecahkan untuk menemukan sedangkan guru berperan sebagai pembimbing atau memberikan petunjuk cara memecahkan masalah itu. Salah satu kebaikan dari metode ini adalah metode ini dapat membantu memperkuat pribadi siswa dengan bertambahnya 
kepercayaan pada diri sendiri melalui proses-proses penemuan. Metode ini berpusat pada anak, misalnya memberi kesempatan pada siswa dan guru berpartisipasi sebagai sesama dalam mengecek ide. Guru menjadi teman belajar, terutama dalam situasi penemuan yang "jawaban"nya belum diketahui sebelumnya.

Berdasarkan uraian di atas, maka dalam pembelajaran IPS saat ini diperlukan strategi pembelajaran yang aktif. Dengan model pembelajaran Discovery Learning diharapkan mampu memberikan solusi yang tepat untuk ketuntasan yang diharapkan. Dari latar belakang di atas maka penulis mengambil judul Implementasi Pendidikan Karakter melalui Penerapan Model Pembelajaran Discovery Learning Madrasah Ibtidaiyah Muhammadiyah Pasir Lor Karanglewas Di Banyumas.

\section{Metode}

Pelaksanaan Pengabdian Kepada Masyarakat ini dilaksanakan di Madrasah Ibtidaiyah Muhammadiyah Pasir Lor Karanglewas, Banyumas. Metode yang digunakan adalah discovery learning karena Metode ini berpusat pada anak, misalnya memberi kesempatan pada siswa dan guru berpartisipasi sebagai sesama dalam mengecek ide. Guru menjadi teman belajar, terutama dalam situasi penemuan yang "jawaban"nya belum diketahui sebelumnya

\section{Hasil}

Model pembelajaran penemuan (discovery learning) merupakan nama lain dari pembelajaran penemuan (Kosasih, 2014: 83). Discovery adalah menemukan konsep melalui serangkaian data atau informasi yang diperoleh melalui pengamatan atau percobaan (Sani, 2014: 97). Discovery terjadi bila individu terlibat, terutama dalam penggunaan proses mentalnya untuk menemukan beberapa konsep dan prinsip (Komara, 2014: 107).

Pembelajaran discovery merupakan metode pembelajaran kognitif yang menurut guru lebih kreatif menciptakan situasi yang dapat membuat peserta didik belajar aktif menemukan pengetahuan sendiri (Sani, 2014: 97). Sesuai dengan namanya, model ini mengarahkan siswa untuk dapat menemukan sesuatu melalui proses pembelajaran yang dilakoninya. Siswa diraih untuk terbiasa menjadi seorang saintis (ilmuwan) (Kosasih, 2014: 83). Discovery sering diterapkan percobaan sains di laboratorium yang masih membutuhkan bantuan guru, yang disebut guided discovery (Sani, 2014: 97). Siswa tidak hanya disodori oleh sejumlah teori (pendekatan deduktif), tetapi mereka pun berhadapan dengan sejumlah fakta (pendekatan induktif). 
Teori dan fakta memperlihatkan bahwa mereka diharapkan dapat merumuskan sejumlah penemuan. Bentuk penemuan yang dimaksud tidak selalu identik dengan suatu teori ataupun benda sebagaimana yang biasa dilakukan kalangan ilmuwan dan profesional dalam pengertian yang sebenarnya. Penemuan yang dimaksud berarti pula sesuatu yang sederhana, namun memiliki makna dengan kehidupan para siswa itu sendiri. Penemuan itu tetap berkerangka pada kompetensi-kompetensi dasar (KD) yang ada pada kurikulum (Kosasih, 2014: 83).

Belajar penemuan (discovery) pada umumnya membutuhkan kemampuan untuk bertanya, mengobservasi, mengumpulkan informasi, mengolah informasi, dan membuat kesimpulan berdasarkan data atau informasi sehingga dapat menemukan hubungan antar variabel atau menguji hipotesis yang diajukan (Sani, 2014: 97). Prinsip belajar yang nampak jelas pada discovery learning adalah materi atau bahan pelajaran yang akan disampaikan tidak disampaikan dalam bentuk final akan tetapi siswa sebagai peserta didik didorong untuk mengidentifikasi apa yang ingin diketahui dilanjutkan dengan mencari informasi sendiri kemudian mengorganisasikan atau membentuk (konstruksi) apa yang mereka ketahui dan mereka pahami dalam suatu bentuk akhir (Komara, 2014: 107).

Metode discovery learning dalam aplikasinya, diharapkan guru berperan sebagai pembimbing dengan memberikan kesempatan kepada siswa untuk belajar secara aktif, sebagaimana pendapat guru harus dapat membimbing dan mengarahkan kegiatan belajar siswa sesuai dengan tujuan (Kurniasih dan Sani, 2014: 65). Metode discovery learning inipun hendaknya guru harus memberikan kesempatan muridnya untuk menjadi seorang problem solver, seorang scientist, historis, atau ahli matematika. Bahan ajar tidak disajikan dalam bentuk akhir, tetapi siswa dituntut untuk melakukan berbagai kegiatan menghimpun informasi, membandingkan mengkategorikan, menganalisis, mengintegrasikan, mereorganisasikan bahan serta membuat kesimpulan-kesimpulan (Kurniasih dan Sani, 2014: 65).

Ciri utama belajar menemukan, yaitu (1) mengeksplorasi dan memecahkan masalah untuk menciptakan, menggabungkan, dan menggeneralisasi pengetahuan; (2) berpusat pada siswa; (3) kegiatan untuk menggabungkan pengetahuan baru dan pengetahuan yang sudah ada (Hosnan, 2014: 284). Bell (dalam Hosnan, 2014: 284) mengemukakan beberapa tujuan spesifik dari pembelajaran dengan penemuan, yakni sebagai berikut:

a. Dalam penemuan siswa memiliki kesempatan untuk terlibat secara aktif dalam pembelajaran. Kenyataan menunjukkan bahwa partisipasi banyak siswa dalam pembelajaran meningkat ketika penemuan digunakan.

b. Melalui pembelajaran dengan penemuan, siswa belajar menemukan pola dalam situasi konkret maupun abstrak, juga siswa banyak meramalkan (extrapolate) informasi tambahan yang diberikan. 
c. Siswa juga belajar merumuskan strategi tanya jawab yang tidak rancu dan menggunakan tanya jawab untuk memperoleh informasi yang bermanfaat dalam menemukan.

d. Pembelajaran dengan penemuan membantu siswa membentuk cara kerja bersama yang efektif, saling membagi informasi, serta mendengar dan menggunakan ide-ide orang lain.

e. Terdapat beberapa fakta yang menunjukkan bahwa keterampilan keterampilan, konsep-konsep dan prinsip-prinsip yang dipelajari melalui penemuan lebih bermakna.

f. Keterampilan yang dipelajari dalam situasi belajar penemuan dalam beberapa kasus, lebih mudah ditransfer untuk aktivitas baru dan diaplikasikan dalam situasi belajar yang baru.

Adapun keuntungan-keuntungan dari Discovery Learning menurut Kurniasih dan Sani (2014: 66) yaitu:

1) Membantu siswa untuk memperbaiki dan meningkatkan keterampilan-keterampilan dan proses-proses kognitif. Usaha penemuan merupakan kunci dalam proses ini, seseorang tergantung bagaimana cara belajarnya.

2) Pengetahuan yang diperoleh melalui metode ini sangat pribadi dan ampuh karena menguatkan pengertian, ingatan, dan transfer.

3) Menimbulkan rasa senang pada siswa, karena tumbuhnya rasa menyelidiki dan berhasil.

4) Metode ini memungkinkan siswa berkembang dengan cepat dan sesuai dengan kecepatannya sendiri.

5) Menyebabkan siswa mengarahkan kegiatan belajarnya sendiri dengan melibatkan akalnya dan motivasi sendiri.

6) Metode ini dapat membantu siswa memperkuat konsep dirinya, karena memperoleh kepercayaan bekerja sama dengan yang lainnya.

7) Berpusat pada siswa dan guru berperan sama-sama aktif mengeluarkan gagasan-gagasan. Bahkan guru pun dapat bertindak sebagai siswa, dan sebagai peneliti di dalam situasi diskusi.

8) Membantu siswa menghilangkan skeptisme (keragu-raguan) karena mengarah pada kebenaran yang final dan tertentu atau pasti.

9) Siswa akan mengerti konsep dasar dan ide-ide lebih baik.

10)Membantu dan mengembangkan ingatan dan transfer kepada situasi proses belajar yang baru.

11)Mendorong siswa berpikir dan bekerja atas inisiatif sendiri.

12)Mendorong siswa berpikir intuisi dan merumuskan hipotesis sendiri.

13)Memberikan keputusan yang bersifat intrinsik; Situasi proses belajar menjadi lebih terangsang. 
14)Proses belajar meliputi sesama aspeknya siswa menuju pada pembentukan manusia seutuhnya.

15)Meningkatkan tingkat penghargaan pada siswa.

16)Kemungkinan siswa belajar dengan memanfaatkan berbagai jenis sumber belajar.

17)Dapat mengembangkan bakat dan kecakapan individu.

Langkah-langkah operasional dari Discovery Learning menurut Kurniasih dan Sani (2014: 67) terdiri dari sebagai berikut:

1. Langkah Persiapan Strategi Discovery Learning

a) Menentukan tujuan pembelajaran.

b) Melakukan identifikasi karakteristik peserta didik (kemampuan awal, minat, gaya belajar dan sebagainya).

c) Memilih materi pelajaran.

d) Menentukan topik-topik yang harus dipelajari peserta didik secara induktif (dari contoh-contoh generalisasi).

e) Mengembangkan bahan-bahan belajar yang berupa contoh-contoh, ilustrasi, tugas dan sebagainya untuk dipelajari peserta didik.

f) Mengatur topik-topik pelajaran dari yang sederhana ke kompleks, dari yang konkret ke abstrak, atau dari tahap enaktif, ikonik sampai ke simbolik.

g) Melakukan penilaian proses dan hasil belajar peserta didik.

2. Prosedur Aplikasi Strategi Discovery Learning

Dalam mengaplikasikan strategi discovery learning di kelas, ada beberapa prosedur yang harus dilaksanakan dalam kegiatan belajar mengajar secara umum sebagai berikut :

a) Stimulation (stimulasi/pemberian rangsangan)

Pertama-tama pada tahap ini pelajar dihadapkan pada sesuatu yang menimbulkan kebingungannya, kemudian dilanjutkan untuk tidak memberi generalisasi, agar timbul keinginan untuk menyelidiki sendiri. Di samping itu guru dapat memulai kegiatan PBM dengan mengajukan pertanyaan, anjuran membaca buku, dan aktivitas belajar lainnya yang mengarah pada persiapan pemecahan masalah. Stimulasi pada tahap ini berfungsi untuk menyediakan kondisi interaksi belajar yang dapat mengembangkan dan membantu peserta didik dalam mengeksplorasi bahan. 
b) Problem statement (pernyataan/identifikasi masalah)

Setelah dilakukan stimulation langkah selanjutnya adalah guru memberi kesempatan kepada peserta didik untuk mengidentifikasi sebanyak mungkin agenda-agenda masalah yang relevan dengan bahan pelajaran, kemudian salah satunya dipilih dan dirumuskan dalam bentuk hipotesis (jawaban sementara atas pertanyaan masalah). Memberikan kesempatan peserta didik untuk mengidentifikasi dan menganalisa permasalahan yang mereka hadapi, merupakan teknik yang berguna dalam membangun peserta didik agar mereka terbiasa untuk menemukan suatu masalah.

c) Data collection (pengumpulan data)

Ketika eksplorasi berlangsung guru juga memberi kesempatan kepada para peserta didik untuk mengumpulkan informasi sebanyak-banyaknya yang relevan untuk membuktikan benar atau tidaknya hipotesis, dengan demikian anak didik diberi kesempatan untuk mengumpulkan (collection) berbagai informasi yang relevan, membaca literature, mengamati objek, wawancara dengan narasumber, melakukan uji coba sendiri dan sebagainya. Konsekuensi dari tahap ini adalah peserta didik belajar secara aktif untuk menemukan sesuatu yang berhubungan dengan permasalahan yang dihadapi, dengan demikian secara tidak sengaja peserta didik menghubungkan masalah dengan pengetahuan yang telah dimiliki.

d) Data processing (pengolahan data)

Pengolahan data merupakan kegiatan mengolah data dan informasi yang telah diperoleh para peserta didik baik melalui wawancara, observasi, dan sebagainya, lalu ditafsirkan, dan semuanya diolah, diacak, diklasifikasikan, ditabulasi, bahkan bila perlu dihitung dengan cara tertentu serta ditafsirkan pada tingkat kepercayaan tertentu. Data processing disebut juga dengan pengkodean coding/ kategorisasi yang berfungsi sebagai pembentukan konsep dan generalisasi. Dari generalisasi tersebut peserta didik akan mendapatkan pengetahuan baru tentang alternative jawaban/ penyelesaian yang perlu mendapat pembuktian secara logis.

e) Verification (pembuktian)

Pada tahap ini peserta didik melakukan pemeriksaan secara cermat untuk membuktikan benar atau tidaknya hipotesis yang ditetapkan tadi dengan temuan alternatif, dihubungkan dengan hasil data processing. Berdasarkan hasil pengolahan data dan tafsiran, atau informasi yang ada, pernyataan atau hipotesis yang telah dirumuskan terdahulu itu kemudian dicek, apakah terjawab atau tidak, apakah terbukti atau tidak. 
f) Generalization (menarik kesimpulan/ generalisasi)

Tahap generalisasi/ menarik kesimpulan adalah proses menarik sebuah kesimpulan yang dapat dijadikan prinsip umum dan berlaku untuk semua kejadian atau masalah yang sama, dengan memperhatikan hasil verifikasi. Berdasarkan hasil verifikasi maka dirumuskan prinsip-prinsip yang mendasari generalisasi. Setelah menarik kesimpulan peserta didik harus memperhatikan proses generalisasi yang menekankan pentingnya penguasaan pelajaran atas makna dan kaidah atau prinsip-prinsip yang luas yang mendasari pengalaman seseorang, serta pentingnya proses pengaturan dan generalisasi dari pengalaman-pengalaman itu.

Dalam kehidupan sehari-hari, kita sering menyamakan istilah karakter dengan watak, sifat, atau pun kepribadian. Padahal, jika ditelisik lebih lanjut, arti kata karakter dengan watak atau pun sifat tidaklah sama. Pada dasarnya karakter merupakan akumulasi dari sifat, watak, dan juga kepribadian seseorang. Selain pengertian ini, ada banyak sekali pengertian kata karakter yang diungkapkan oleh para ahli seperti beberapa contohnya adalah sebagai berikut :

1. Menurut Maxwell, karakter jauh lebih baik dari sekedar perkataan. Lebih dari itu, karakter merupakan sebuah pilihan yang menentukan tingkat kesuksesan.

2. Menurut Wyne, karakter menandai bagaimana cara ataupun teknis untuk memfokuskan penerapan nilai kebaikan ke dalam tindakan atau pun tingkah laku.

3. Menurut Kamisa, pengertian karakter adalah sifat - sifat kejiwaan, akhlak, dan budi pekerti yang dapat membuat seseorang terlihat berbeda dari orang lain. Berkarakter dapat diartikan memiliki watak dan juga kepribadian.

4. Menurut Doni Kusuma, karakter merupakan ciri, gaya, sifat, atau pun karakteristik diri seseorang yang berasal dari bentukan atau pun tempaan yang didapatkan dari lingkungan sekitarnya.

5. Menurut W. B. Saunders, karakter merupakan sifat nyata dan berbeda yang ditunjukkan oleh individu. Karakter dapat dilihat dari berbagai macam atribut yang ada dalam pola tingkah laku individu.

6. Menurut Gulo W. Pengertian karakter adalah kepribadian yang dilihat dari titik tolak etis atau pun moral (seperti contohnya kejujuran seseorang). Karakter biasanya memiliki hubungan dengan sifat - sifat yang relatif tetap.

7. Menurut Alwisol, karakter merupakan penggambaran tingkah laku yang dilaksanakan dengan menonjolkan nilai (benar - salah, baik - buruk) secara implisit maupun eksplisit. Karakter berbeda dengan kepribadian yang sama sekali tidak menyangkut nilai - nilai. 
Karakter yang dimiliki oleh seseorang pada dasarnya terbentuk melalui proses pembelajaran yang cukup panjang. Karakter manusia bukanlah sesuatu yang dibawa sejak lahir. Lebih dari itu, karakter merupakan bentukan atau pun tempaan lingkungan dan juga orang - orang yang ada di sekitar lingkungan tersebut. Karakter dibentuk melalui proses pembelajaran di beberapa tempat, seperti di rumah, sekolah, dan di lingkungan sekitar tempat tinggal. Pihak - pihak yang berperan penting dalam pembentukan karakter seseorang yaitu keluarga, guru, dan teman sebaya. Karakter seseorang biasanya akan sejalan dengan perilakunya. Bila seseorang selalu melakukan aktivitas yang baik seperti sopan dalam berbicara, suka menolong, atau pun menghargai sesama, maka kemungkinan besar karakter orang tersebut juga baik, akan tetapi jika perilaku seseorang buruk seperti suka mencela, suka berbohong, suka berkata yang tidak baik, maka kemungkinan besar karakter orang tersebut juga buruk.

Amanat Undang-undang Dasar 1945, tentang pendidikan dasar dimaknai sebagai pendidikan di Sekolah Dasar dalam upaya mencerdaskan dan mencetak kehidupan bangsa yang bertaqwa, cinta dan bangga terhadap bangsa dan negara, terampil, kreatif, santun serta mampu menyelesaikan permasalahan di lingkungannya. Madrasah Ibtidaiyah setara dengan sekolah dasar. Undang-undang Sistem Pendidikan Nasional ((UU No. 20 Tahun 2003) Pasal 17 mendefinisikan Pendidikan dasar sebagai berikut: a) Pendidikan dasar merupakan jenjang pendidikan yang melandasi jenjang pendidikan menengah, b) Pendidikan dasar berbentuk sekolah dasar (SD), madrasah Ibtidaiyah (MI), atau bentuk lain yang sederajat serta sekolah menengah pertama (SMP) dan madrasah Tsanawiyah (MTs) atau bentuk lain yang sederajat. Sekolah dasar adalah jenjang paling dasar pada pendidikan formal di Indonesia, ditempuh selama 6 tahun dan selanjutnya dapat meneruskan ke jenjang sekolah menengah pertama atau yang sederajat.

Madrasah Ibtidaiyah lebih menonjolkan muatan keagamaan yang dijabarkan dalam beberapa mata pelajaran, seperti Al-Qur'an Hadits, Aqidah Akhlak, Fiqih, Sejarah Kebudayaan Islam (SKI), dan Bahasa Arab, dan lainnya hingga muatan pendidikan Islam lebih banyak. Selain itu suasana keagamaan sangat kental berupa: suasana kehidupan madrasah yang agamis, sasaran ibadah yang lebih utama, Metode pembelajaran juga berkesan agamis dalam penyajian bahan pelajaran bagi setiap mata pelajaran, sehingga mengharuskan kualifikasi guru beragama Islam serta memiliki akhlak mulia. Pembelajaran yang dilaksanakan di Madrasah Ibtidaiyah merupakan suatu kegiatan yang kompleks, di mana kurikulum sesuai dengan kurikulum nasional dan tambahan pendidikan Agama sebagai karakteristik dari Madrasah ibtidaiyah. Pada hakikatnya pembelajaran tidak sekedar menyampaikan pesan pembelajaran kepada peserta didik, akan tetapi merupakan aktivitas professional yang menuntut guru untuk dapat menggunakan keterampilan dasar mengajar secara terpadu, dan mampu menciptakan situasi dan kondisi yang memungkinkan peserta didik dapat belajar secara efektif dan efisien. 
Guru dalam salah satu kompetensinya, dituntut sikap profesional disamping kepribadian, sosial, dan pedagogik. Pembelajaran di madrasah Ibtidaiyah di mana muatan pengetahuan agama lebih banyak diberikan pada peserta didik memiliki konsekuensi tersendiri. Para guru dituntut untuk dapat menyampaikan materi secara maksimal kepada peserta didik, tidak membuat bosan dan jenuh para peserta didik, sehingga tujuan pembelajaran tercapai. Kondisi ini tidak mudah terlebih pada jenjang pendidikan dasar, karakter peserta didik masih berada pada tahap. Terkadang, ketika pembelajaran berlangsung konsentrasi anak tidak bisa penuh, bahkan ada juga yang masih jalan-jalan di kelas dengan tujuan yang tidak jelas, dan perilaku-perilaku lain yang mengindikasikan mereka belum cukup dapat konsentrasi dalam belajar. Guru perlu dibekali metode-metode pembelajaran yang sifatnya mempermudah pelaksanaan proses belajar baik diluar maupun di dalam kelas, sehingga peserta didik pun nyaman. Demikian halnya dalam pendidikan karakter di Madrasah Ibtidaiyah, menjadi materi yang disisipkan pada setiap mata pelajaran.

\section{Kesimpulan}

Model pembelajaran Discovery Learning dalam implementasi pendidikan karakter dapat didesain secara khusus dengan tujuan pembelajaran yang jelas, dan pembelajaran dilakukan dengan menggunakan rambu-rambu (RPP) cara mengajar guru dan aktivitas siswa dan catatan-catatan bagaimana merespon kesulitan cara belajar siswa. Sebelumnya guru mengobservasi kesulitan-kesulitan dan masalah-masalah yang dihadapi siswa dalam PBM, guru melaksanakan pengkajian atau telaah yang dilakukan oleh kelompok untuk menggambarkan strategi-strategi pembelajaran yang dilakukan dan mendapatkan data tentang cara belajar siswa, berbagi pengalaman dan pengetahuan tentang temuan dan hasil observasi, dan menggambarkan kesimpulan tentang kemajuan siswa dalam mencapai tujuan belajar.

Desain yang digunakan dalam hal ini menggunakan desain Kemmis dan Mc Taggart yang merupakan pengembangan dari model Kurt Lewin. Pada model ini tindakan (acting) dan observasi (observing) dijadikan sebagai satu kesatuan karena mereka menganggap bahwa kedua komponen tersebut merupakan dua kegiatan yang tidak bisa dipisahkan. Pelaksanaan pembelajaran dilakukan satu kali pembelajaran artinya hanya komponen tindakan dengan pengamatan dijadikan sebagai satu kesatuan dimana ketika seorang peneliti melakukan tindakan dalam melakukan pengamatan, karena kegiatan itu dilakukan dalam satu kesatuan waktu secara bersamaan. Jadi pada intinya model ini terdiri dari beberapa tahapan-tahapan diantaranya yaitu (1) perencanaan (planning); (2) tindakan (action); (3) observasi (observation); (4) refleksi (reflection). 


\section{Daftar Referensi}

Basri, Hasan. Filsafat Pendidikan Islam. (Bandung: CV Pustaka Setia, 2009).

Damon, William,Bringing in a New Era in Character Education, (California:Press Hoover Institution Stanford University, 2002), E-Book

Herdiansyah, Haris. Metodologi Penelitian Kualitatif untuk IImu-ilmu Sosial,(Jakarta: Salemba Humanika, 2014).

Irwin, David. Jo Straker and Allen Hill, Outdoor Education In Aotearoa New Zealand, (New Zealand: Cpit, 2012).

Kerangka Acuan Pendidikan Karakter Tahun Anggaran 2010, Direktorat Ketenagaan

Direktorat Jenderal Pendidikan Tinggi Kementerian Pendidikan Nasional, 2010.

Kesuma, Dharma dkk. Pendidikan Karakter Kajian Teori dan Praktik di Sekolah, (Bandung: PT Remaja Rosdakarya, 2013).

Koesoema A, Doni.Pendidikan Karakter Strategi Mendidik Anak di Zaman Global. (Jakarta: Grasindo, 2015).

Maksudin, Pendidikan Karakter Nondikotomik, (Yogyakarta: Pustaka Pelajar, 2013). Marzuki, Pendidikan Karakter Islam, (Jakarta: AMZAH, 2015).

Moeliono, Anton M. ddk, Kamus Besar Bahasa Indonesia, (Jakarta: Balai Pustaka, 1990).

Mu'in, Fatchul, Pendidikan Karakter Konstruksi Teoritik dan Praktik, (Yogyakarta: Ar-Ruzz Media, 2013).

Panduan Pelaksanaan Pendidikan Karakter,Kementerian Pendidikan Nasional Badan Penelitian Dan Pengembangan Pusat Kurikulum Dan Perbukuan,2011.

Quay, John dan Jayson Seamen, John Dewey and Education Outdoor Making Sense of the 'Educational Situation' through more than a Century of Progressive Reforms, (Netherlands: Sense Publishers, 2013).

Rohman, Arif. Memahami IImu Pendidikan. (Yogyakarta: CV. Aswaja Pressindo, 2013).

Samani, Muchlas dan Hariyanto, Konsep dan Model Pendidikan Karakter, (Bandung: PT Remaja Rosdakarya, 2011).

Setiyorini Dwi, Nunung, Pembelajaran Kontekstual IPA Melalui Outdoor Learning di $S D$ Alam Ar-Ridho Semarang, Malang: Program Pasca Sarjana UIN Malang Prodi PGMI, 2015.

Sugiyono. Metodologi Penelitian Kuantitatif Kualitatif dan R\&D. (Bandung: ALFABETA, 2012).

Suma, Muhammad Amin. Ulumul Qur'an. (Jakarta: PT RajaGrafindo Persada, 2013). Sumiati dan Asra, Metode Pembelajaran, (Bandung: CV Wacana Prima, 2007).

Undang-Undang Sistem Pendidikan Nasional Nomor 20 Tahun 2003

Vera, Adelia. Metode Mengajar Anak di Luar Kelas (Outdoor Study). (Jogjakarta: DIVA Press, 2012) 
Warso Doso Dwi Wasisto, Agus Pembelajaran Tematik Terpadu Penilaiannya, (Yogyakarta: Graha Cendekia, 2013).

Wiyani Ardy, Novan, Desain Pembelajaran Pendidikan, (Yogyakarta: Ar-Ruzz Media, 2013).

Yaumi, Muhammad. Pendidikan Karakter Landasan, Pilar dan Implementasinya. (Jakarta: Kencana, 2014). 